\title{
Internet resources for business
}

\author{
By Leslie M. Haas
}

\section{Sample the many facets of business information on the Net}

$\mathbf{N}$ ew sources are being added to the Internet daily, and many of us have a difficult time keeping track of what is out there in our subject area. One solution to this problem has been to create subject bibliographies of what is available and make them accessible via anonymous $\mathrm{ftp}$ and gophers to those who are interested.

Approximately a year ago, a question was posted on BUSLIB-L asking for help finding such a guide for business. On discovering that there wasn't one available, several librarians decided to create one. The result was Business Sources on the Net (BSN). Currently, $B S N$ is divided into nine different files, each on a different business subject. There are plans to add new subjects as more sources become available on the Net and to update the existing files.

The files are available via anonymous ftp to ksuvxa.kent.edu in the Library Directory and also through the gopher at refmac.kent.edu 70 under the name Business Sources on the Net.

The resources available to business researchers are varied. The following are highlights from each of the files in the directory. Listed at the end of each section are the names of those persons responsible for putting that section together.

The connection information includes the protocol to be used (e.g., telnet, ftp) followed by the address of the host site and any subdirectories of login information. Example: Protocol//address/subdirectory/subdirectory.

\section{General business sources}

The following resources are general business sources that will be useful to people in different areas of business. Sources in this section include: telephone books, current events, and government information.

- Small Business Bibliography. Gopher: //gopher.fsu.edu/libraries/Strozier Library Research Guides/Topic or Alph List/Small Business Bibliography. A brief bibliography and "how to find" guide for small business clientele.

- Gross State Product Tables. Gopher: //lib.umich.edu/Social Sciences Research/Economics. This database contains economic information on the state level.

- Washlaw. Telnet://acc.wuacc.edu Login: washlaw. Information on this system includes: The 1993-94 U.S Budget, 1990 Census data, and Congressional bills. Users can search the system by types of law (commercial, intellectual property, disability, etc.) Washlaw also allows users to connect to other Internet tools.

- Fedworld Electronic Marketplace. Telnet://fedworld.gov/name/user-id. This resource is a gateway to many government bulletin boards which may include data sets. Two boards that may be of interest to business persons are: The Census Board and the GPO Bulletin Board. Current Industrial Reports and Census Board News Releases are just two of the sources that are accessible using these bulletin boards.-Elizabeth B. Richmond, University of Wisconsin-Eau Claire; Lelab Lugo, University of Wisconsin-Stout; Michele McKnelly, University of Wisconsin-River Falls

\section{Economics}

The following resources cover the area of economics. 
- Economic Bulletin Board at the University of Michigan: UNA.HH.LIB.UMICH. EDU. This is by far one of the most important sources of economic data on the Internet. This site downloads approximately one third of all the files available on the Economic Bulletin Board. The information contained on this bulletin board is usually current textual information. It is available for both ftp and gopher file transfers.

- Sam Houston State University. Gopher://niord.shsu.edu/. Documents included at this gopher site include selected economic bil)liographies and the text of the NAFTA documents.

- Federal Reserve Bank of Boston. Gopher://NEEEDC.UMESBS.MAINE.EDU/FRBB/ This bulletin board contains regional economic data from the Federal Reserve Bank of Boston. Both text and compressed files are available by ftp.

- CSEMILISTHASARA11.BITNET. To subscribe send a message to saraserv@hasara11. bitnet with the line: "Subscribe CSEMLIST Your Name". This list serves as an information distribution system for researchers in the field of computational economics.-Carl Braun, Syracuse University

\section{Foreign statistics, economic trends, and international management}

Foreign and international items in this section are defined from the U.S.'s perspective.

- 10 a.m. EST Foreign Exchange Rates. Gopher://una.hh.lib.umich.edu/ebb/monetary/ tenfx.frb.

- Historic Price Data for U.K., U.S., Canada, Norway, and Sweden. Gopher:// niord.shsu.edugopher_root:[_Data.Economics. Price].

\section{Correction}

One of the footnotes in the article "Selecting a preservation photocopy machine" by Dorothy W. Wright (January 1994) gave the wrong date. The second note referencing the permanent paper standard gave the date as 1984 . The standard was revised in 1992 and should have been referenced as: ANSI/NISO Z39.48-1992, Permanence of Paper for Library Printed Materials. The editors regret the error.
- International Marketing Insights, C\&E Europe. Gopher://nestroy.we-wein.ac.at/ 1/pub/cerro/profiles. Reports by the U.S. embassies and consulates on important developments with trade and investment implications.

- Journal of the International Academy of Hospitality Research. To subscribe contact the editor/publisher at JIAHRED@VTM1.CC. VT.EDU. This journal publishes refereed articles on basic and applied research on aspects of hospitality and tourism. It is published by the Scholarly Communications Project of Virginia Polytechnic Institute and State University, Blacksburg.-Mel Westerman and Gary White, Pennsylvania State University

\section{Finance and banking}

Sources of information in the three areas of corporate finance are presented in this section: money, banking, and credit.

- National Bureau of Economic Research. FTP:/nber/harvard/edu//. These three files contain the Survey of Consumer Finance.

- New England Banking Data. FTP:// neeedc.umesbs.maine.edu/edu/frbb/banking. These files contain information on the New England economy. Performance measures for banks in the New England area and financial statements are two of the files available from this site.

- E-Finance. To subscribe send a message to listserv@templevm with the line "Subscribe E-Finance Your first name Your last name". The Electronic Journal of Financing disseminates information of interest to academic researchers in finance.-Jan Tudor, Willamette University; Theodora Haynes, Rutgers University; Shari Buxbaum, Michigan State University

\section{Human resources}

Information on human resources/personnel management is available in this section. (Note: No benchmarking information or local human resources operations have been included in this file.)

- Human Resources and Industrial Psychology Section of the Directory of Scholarly Electronic Conferences. Gopher:// gopher.uask.ca./Computing/Internet Information/Directory of Scholarly Electronic Conferences/Business, Miscellaneous Academic and News/Human Resources and Industrial Psychology. Major discussion lists in the area of human resources and industrial psychology are listed in this section of the directory. 


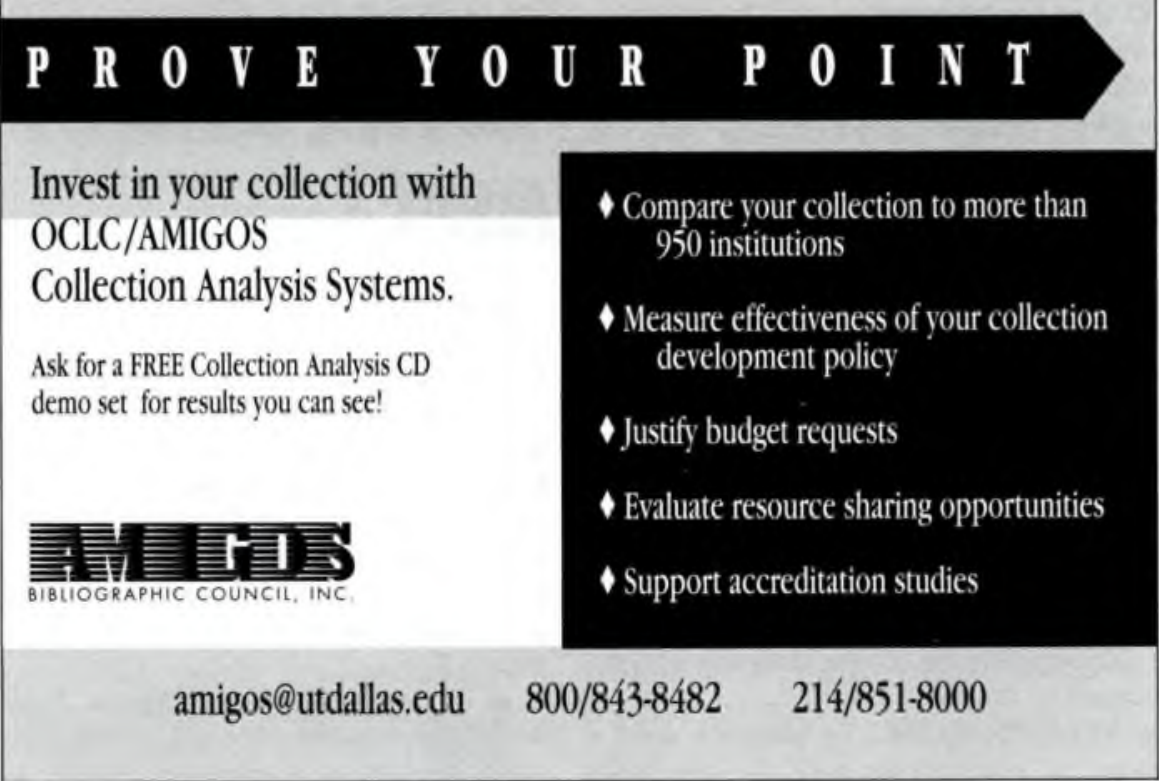

- Employment Statistics, U.S. Economic Bulletin Board. Gopher://una.hh.lib.umich. edu/ebb/employment/**; ftp:/una.hh.lib.umich. edu/ebb/employment/*"*; ftp://una.hh.lib. umich.edu/ebb/bin [binary transfer for larger files]. These files contain a variety of statistical and textual information on employment and labor. Some of the files available in the employment directory include: BLS Employment Cost Index, Employment Situation, civilian labor force and unemployment by state, household employment statistics, major collective bargaining settlement, average wage and compensation tables, and unemployment rates by state and selected industry divisions.

- HRIS-L@UALTVM.BITNET. To subscribe send a message to listserv@ualtvm with the line "Subscribe HRIS-L Your first name Your last name". Human Resources Information (Canada) E-Conference is for payroll, personnel, and administration employees. This list is moderated.-Hope N. Tillman, Babson College; Gary White, Pennsylvania State University; Theo Haynes, Rutgers University

\section{Management science, statistical methods, and operations}

Coverage of these topics has been combined because of the overlap in the resources available. (Note: Course descriptions are excluded from this listing.)
- Laboratory of Manufacturing $\overline{R e}$ search, Working Paper, Faculty of Management, University of Toronto. Ftp:// fmgmt.mgmt.utoronto.ca/*. The working papers are either forthcoming in specified journals or submitted for publication.

- CHANCE. Gopher://cameron.geom.umn. edu/CHANCE/ ${ }^{\prime \prime}$.". This database contains material designed to be helpful in teaching a CHANCE course. CHANCE is a case study course based on current chance events as reported in the daily newspapers.

- MNF-STRATEGY@MAILBASE.AC.UK. To subscribe send a message to mailbase@ mailbase.ac.uk with the line "join MNF-STRATEGY Your first name Your last name". The Manufacturing Strategy is a forum for researchers and practitioners in the fields of manufacturing strategy formulation and performance measurement system design.

- SCI.OP-RESEARCH. This Usenet Newsgroup is the umbrella group for the operations research/management community. Focus is on research, application, and teaching.-Hope $N$. Tillman. Babson College; Perry Horner and Terry Meyer, Arizona State University; Ann Scholz, University of Wisconsin-Parkside

\section{Accounting and taxation}

The main sources of information available in the area of accounting and taxation come from 
the General Accounting Office (GAO). The $\mathrm{GAO}$ is an investigative arm of Congress that examines issues concerning the receipt and disbursement of public funds.

- Wiretap Internet. Gopher://wiretap. spies.com/gov. This site contains GAO publications including GAO High Risk Reports, GAO Tecbnical Reports, and GAO Miscellaneous Reports.

- Villanova Tax Law Compendium. Gopher://ming.law.vill.edu/.taxlaw./. This is a collection of student tax papers available to students and practitioners through the Villanova gopher.

- CapAccess. Telnet://cap.gwu.edu/go federal/Legislative Branch Menu. Logon: Guest. Password: Visitor. The National Capital Area Public Access Network in cooperation with GAO is providing access to the GAO Daybook. The Daybook lists the current daily reports and testimony by the GAO.

- FEDTAX-L@SHSU. To subscribe send a message to listserv@shsu with the line "subscribe FEDTAX-L Your first name Your last name". This unmoderated discussion list focuses on both the practical and academic viewpoints of various federal taxation issues.-Barbara Mento, Boston College; Sharmon Kenyon, Humboldt State University; Wendy Diamond, University of Califormia, Berkeley; Barbara Butler, University of Nevada, Reno

\section{Management including public and nonprofit organizations}

Concentration in this section is on sources of management information in organizational behavior, organization theory, management of new and small business, corporate and strategic planning, and the management of public and nonprofit organizations.

- The Management Archive (University of Minnesota). Gopher://chimera.sph.umn. edu. The Archives provide access to contributed papers and preprints in the management and organizational sciences, recent paper calls, course syllabi, teaching materials, etc.

- CNI-MANAGEMENT@CNI.ORG. To subscribe send a message to listserv@cni.org with the line "subscribe CNI-MANAGEMENT Your first name Your last name". This forum is for those interested in issues about the training and education of management professionals.

- ESBDC-L@FERRIS. To subscribe send a message to listserv@ferris with the line "subscribe ESBDC-L Your first name Your last name". This unmoderated discussion group is aimed at facilitating discussion among small business development centers.-Jan Tudor and Sridhar Krishan, Willamette University; Theodora Haynes, Rutgers University

\section{Computers}

This section focuses on computers as they relate to the general area of business. (Note: Excluded in this section are course descriptions, local operations, and files that are specific to a brand of hardware or software.)

- Computer Science and Related Areas section of the Directory of Scbolarly Electronic Conferences. Gopher://gopher.usask. $\mathrm{ca} /$ Computing/Intemet Information/Directory of Scholarly Electronic Conferences/Computer Science and Related Areas. Computer conferences of the well-networked computer scientist community.

- Art of Tecbnology Digest. Ftp://ftp. wuarchive.wustl.edu/doc/misc/aot/*. This journal is devoted to sharing information among computerists and to the presentation and debate of diverse views.

- Computing Electronic Serials. Gopher://gopher.cic.net/e-serials/general/computing. A variety of titles are represented including: Apple, Interpersonal Computing and Technology, and Computer Networking Journals.-Hope Tillman, Babson College

\section{Investment information}

There has always been keen interest in investment data via the Internet. The following sources focus on those sources that are of interest to the individual investor. (Note: As with paper sources, interest may wane and the source could disappear.)

- E Mail Quoter. Ftp://ftp.dg-rtp.dg.com/ pub/misc.invest/quote dump. Contains selected daily prices and market oscillator readings. Data is also ranked by advances, declines, percent change and a variety of other measures. (Note: Information is deemed reliable, but never guaranteed.)

- Financial Economics Network (AFA_FIN). Send a message to MARRM@ CLEMSON.EDU (Wayne Marr) or TRIMBLE@ VANCOUVER.WSU.EDU (John Trimble) to subscribe to this service. AFA_FIN contains eleven moderated lists on a variety of topics including real estate, banking, international finance, and investments.-Pearl Alberts, O'Neill Library 


\section{A BETTER WAY To SEARCH DATABASES} W ${ }_{\text {committed to better search software }}^{\text {started in } 1985 \text {, database searchers }}$ design. We became the premier vendor of Medline, then expanded our catalog to other databases. Last year we won Information World Review's PRODUCT OF THE YEAR for faster, easier search software. But a better way means meeting the evolving needs - individual and campus wide - of today's library users.

Announcing OVID: a database interface $\mathrm{A}_{\text {so flexible it molds itself to your search }}$ environment.

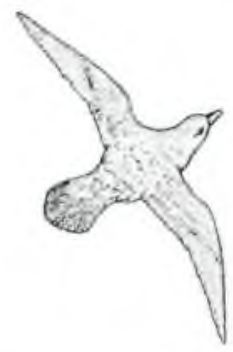

With OVID you're free to move from one operating system to another without retraining. OVID's Common User Interface assures identical functionality in DOS, Windows and UNIX.

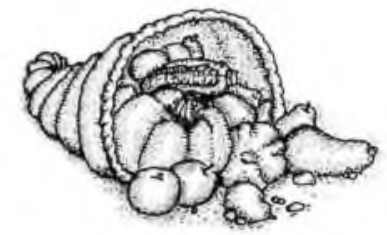

There's an unprecedented array of search tools - indexes, thesauri, limits and fields - many never before available in an interface. They're all standard OVID features.

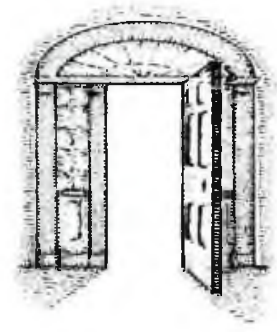

A baven for beginners, OVID's Easy Mode has on screen prompts. The more experienced can pull-down menus showing an array of search options. Experts will feel at bome using online syntax.

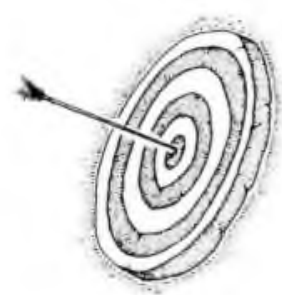

Search with natural language if you like. OVID mapping cuts through the mystery of controlled vocabularies, homing in on precisely matching subject beadings.

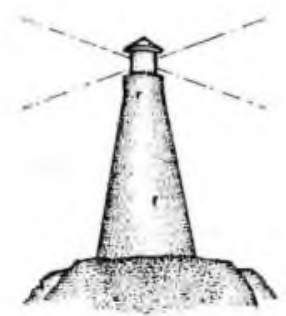

HELP for every search function is context-sensitive and on screen, never more than a keystroke or mouse click away.

\section{OVID. A better way to search ERIC, Current Contents", PsycINFO', Medline, Readers' Guide Abstracts, EMBASE and more.

